\title{
Literatura universal: a tradução na época de Goethe
}

\section{Universal Literature: Translation in Goethe's Times}

\section{Roger Roothaer*}

Resumo: Neste artigo são analisados diferentes aspectos da tradução no período mais profícuo da tradução literária na Alemanha, através de uma grande variedade de citações históricas de escritores que se manifestaram sobre a recepção literária ou atuaram como tradutores no final do séc. XVIII e no início do séc. XIX, como Schiller, Goethe, Schlegel e outros.

Palavras-chave: tradução - tradução literária - recepção de obras literárias

Abstract: The article analyses different aspects of translation in the richest period of literary translation in Germany through a huge variety of historic citations of authors who either commented reception of translated literature or worked as translators themselves in the end of the 18th and beginning of the 19th Century, such as Schiller, Goethe, Schlegel and others.

Key-words: translation - literary translation - reception of literature

Zusammenfassung: In diesem Artikel werden verschiedene Aspekte der Übersetzung in der wichtigsten Zeit der literarischen Übersetzung in Deutschland anhand einer großen Vielfalt an historischen Zitaten von Schriftstellern, die sich Ende des 18. und Anfang

\footnotetext{
"Professor emérito da Hogeschool voor Vertalers en Tolken (Bruxelas), falecido em 1999. 0 presente texto é a tradução dos artigos: "Weltliteratur: Übersetzen zu Goethes Zeiten I" (1990). In: Germanistische Mitteilungen 32/1990, Bruxelas, pp. 15-27, e Weltliteratur: Übersetzen zu Goethes Zeiten II (1991). In: Germanistische Mitteilungen 33/1991, Bruxelas, pp. 11-33.
} 
des 19. Jh. entweder über die Rezeption übersetzter Literatur äußerten oder selbst als Übersetzer tätig waren, wie Schiller, Goethe, Schlegel u.a., analysiert.

Schlüsselwörter: Übersetzung - literarische Übersetzung - Rezeption literarischer Werke

\section{Introdução à tradução}

É com grande prazer que apresentamos nesta revista um artigo do professor de Germanística Roger Roothaer, da Bélgica, sobre a tradução na época de Goethe. 0 leitor ficará surpreso com a vivacidade do texto e a atualidade de muitas questões ligadas à tradução literária. Além disso, o artigo traz uma grande quantidade de citações históricas valiosas acerca da tradução de diferentes autores, que são, em sua maioria, contemporâneos de Goethe.

A tradução do artigo foi realizada em diferentes etapas por alunos da disciplina "Tradução: Teoria e Prática" e por outros alunos de Letras/Alemão da Universidade de São Paulo. É uma satisfação finalmente tornar este texto acessível aos nossos leitores de língua portuguesa e continuar, assim, reforçando a função da tradução como forma de difusão do conhecimento. Além das notas do próprio autor Roger Roothaer, que constam no artigo original e estão acompanhadas com suas iniciais (RR), incluímos algumas notas, marcadas com "N.d.T." (nota do tradutor), com referências a eventuais traduções já existentes em língua portuguesa ou com outras informações complementares. Optamos também por verter as citações para o português atual sem tentar imitar artificialmente marcas históricas na linguagem e manter o formato do texto de partida.

Agradecemos ao Prof. Dr. Torsten Leuschner da Universidade de Gante (Gent), Bélgica, editor do periódico Germanistische Mitteilungen, publicado pela Associação Belga de Germanistas e Professores de Alemão (Belgischer Germanisten- und Deutschlehrerverband, www.bgdv.be), por ceder os direitos 
ROOTHAER, R. - Literatura universal: a tradução na época de Goethe

de tradução do artigo para o português e fornecer alguns dados biográficos sobre o autor.

Roger Roothaer nasceu em 25 de janeiro de 1925 em Oostende (Bélgica) e estudou letras anglo-germânicas, com ênfase em inglês, na Universidade de Gante, de 1944 a 1948. Depois de concluir seus estudos, trabalhou até 1960 como professor de inglês na Academia Técnica, situada no bairro Anderlecht de Bruxelas, onde também participou ativamente da vida cultural flamenga. Paralelamente, graduou-se em Direito, mas não chegou a exercer a profissão.

Em 1960 assumiu um cargo de docente na recém-fundada Academia de Tradução e Interpretação de Bruxelas. Quando esta foi promovida a Escola Superior Técnica (Hogeschool voor Vertalers en Tolken) em 1964, recebeu o título de professor universitário. Em 1978 assumiu a função de vice-reitor, cargo em que permaneceu até tornar-se professor emérito em 1989. Durante muitos anos, atuou na Associação de Ex-alunos do Curso de Letras (Bond van Gentse Germanisten, formada por profissionais de Letras Anglo-Germânicas) e foi membro de sua diretoria por vários anos. Não há certeza acerca do ano de sua morte, mas ela provavelmente ocorreu em 1999.

0 artigo de Roger Roothaer foi publicado originalmente em duas partes: 1) Weltliteratur: Übersetzen zu Goethes Zeiten I (1990). In: Germanistische Mitteilungen 32/1990, Bruxelas, pp. 15-27.

2) Weltliteratur: Übersetzen zu Goethes Zeiten II (1991). In: Germanistische Mitteilungen 33/1991, Bruxelas, pp. 11-33.

Esperamos que esta tradução sirva de apoio para estudos posteriores sobre o assunto e desejamos a todos uma excelente leitura.

Tinka Reichmann Universidade de São Paulo

\section{Tradução:}

David Edson Farah, Fabrício Waltrick, Iracema Aparecida de Oliveira, Josefa Juliana dos Santos Andrade, Laura da Silva Monteiro Chagas, Maria de Fátima Leite Ancelmo, Raul Coelho de Oliveira Araújo. 


\section{Revisão:}

David Edson Farah, Flora Azevedo Bonatto

\section{Coordenação:}

Tinka Reichmann

\section{Revisão final:}

Tinka Reichmann, Tercio Loureiro Redondo

\section{Introdução}

"Apesar de tudo aquilo que se possa dizer da insuficiência da tradução, ela é e permanece, sim, um dos mais importantes e dignos negócios no trânsito geral do mundo". ${ }^{1}$

Johann Wolfgang von Goethe

Por ocasião de uma visita ao Arquivo Literário Alemão e ao Museu Nacional Schiller, em Marbach, descobri que em 1982 houve uma exposição sobre "a tradução na época de Goethe”. Acabara de ser publicada a segunda edição do catálogo da exposição: Weltliteratur - Die Lust am Übersetzen im J ahrhundert Goethes [Literatura Universal - o prazer de traduzir no século de Goethe] (MARBACH 1989). ${ }^{2}$ Ele é bastante interessante sob diversos aspectos: primeiramente, por ser uma rica fonte de leitura no que concerne a concepções teóricas e a métodos práticos de tradução daquele tempo; e, em segundo lugar, por servir de base para uma breve comparação entre os problemas de hoje e os daquela época.

\footnotetext{
${ }^{1}$ GOETHE, 1977, p. 932-3, citação em português apud HEISE, Eloá. Weltliteratur, um conceito transcultural. In: Revista Brasileira de Literatura Comparada, v. 11, pp. 35-57, 2007. p. 51. (N.d.T.)

2 Todas as citações do catálogo, a não ser quando especificadas: MüLLER, 1989. Neste caso: MüLLER, Rosemarie: Goethe als Übersetzer [Goethe como tradutor], in Liber Amicorum R. Roothaer, p. 68-85, Escola de Tradutores e Intérpretes, Trierstraat 84, 1040 Bruxelas.
} 
ROOTHAER, R. - Literatura universal: a tradução na época de Goethe

O livro não apresenta tratados teóricos sobre a tradução. No entanto, os excertos que ilustram os diferentes aspectos da tradução são tão abundantes e tão excepcionalmente bem escolhidos que, sem dúvida, contêm informação suficiente para apresentar as concepções de então.

\subsection{A diferença entre expressivo e informativo}

É absolutamente natural que, com algumas poucas exceções, apenas a tradução literária seja objeto de discussão. Permanece inexplorada a considerável diferença que observamos entre as traduções de conteúdo meramente informativo - juntamente com aquelas destinadas à publicidade e ao jornalismo - e as traduções literárias. Nas palavras de Christian Garve, tradutor da Ética de Aristóteles (1798), é perceptível, nas entrelinhas, uma espécie de declaração de princípios. Em seu prefácio ele diz: "Acredito que a inteligibilidade seja a primeira virtude de um tradutor; que a brevidade deva vir logo em seguida; e que a correspondência com o estilo do autor seja apenas um objetivo secundário que nunca poderá ser completamente atingido e que, muitas vezes, compromete objetivos mais elevados."

Essa opinião é de fácil compreensão e, de uma forma geral, é aceita ainda hoje quando se trata de textos que não apresentam um intuito literário, predominantemente expressivo, mas de textos científicos, técnicos ou informativos de modo geral. Vale ressaltar que, quanto mais um texto está próximo das ciências humanas, maior também é o seu aspecto expressivo.

\subsection{Autores-tradutores bons e ruins}

$\mathrm{Na}$ época de Goethe, muitos poetas também eram tradutores, como ficará claro mais adiante. Alguns não eram particularmente bons nesse ramo. Então, dava-se-lhes o conselho de se dedicar à tradução em vez de escrever obras de pouco valor: "[...] seria melhor que os nossos maus escritores se tornassem tradutores, em vez de, a exemplo do que ocorre na França, escreverem romances miseráveis ou, como na Inglaterra, atacarem o governo 
ou a religião, arruinando tanto a Igreja quanto o Estado. Um ou outro talvez tivesse se tornado um notório envenenador, um Voltaire, se não tivesse encontrado nas traduções uma ocupação melhor." (Johann Gottfried Gellius, Briefe die Neueste Litteratur betreffend [Cartas acerca da literatura mais recente], 1762).

\subsection{Tradutores desconhecidos}

Vez por outra, o tradutor permaneceu desconhecido, como, por exemplo, aquele que em 1819 publicou uma tradução das fábulas de La Fontaine (ver item 1.6.). Mas, às vezes, o anonimato foi intencional, quando $o$ conteúdo podia ser considerado escandaloso do ponto de vista moral: é o que se passou com o Satyricon: Begebenheiten des Enkolp (1773) [Satíricon: Acontecimentos de Encólpio], de Petrônio, (até mesmo com indicação incorreta de ano e lugar!), traduzido, como se soube mais tarde, por Johann Jacob Wilhelm Heinse.

Uma outra razão para isso foi a tradução de escritos revolucionários a partir do francês: Dietrich von Holbach, tradutor de J.-B. de Mirabaud, Système de la nature ou les lois du monde physique et du monde moral (1770) [Sistema da natureza ou as leis do mundo físico e do mundo moral]. Somente depois de 20 anos soube-se quem fora o tradutor; ou E. Sieyès' Politische Schriften vollständig gesammelt von dem deutschen Übersetzer [Escritos Políticos de E. Sieyès: compilação completa feita pelo tradutor alemão] (1796), tradutor: Konrad Engelbert Oelsner - inicialmente publicado sem menção do nome do tradutor; ou ainda: Reflections on the Revolution in France [Reflexões sobre a Revolução na França] (1791), de E. Burke, cujo tradutor permaneceu desconhecido.

\subsection{Tradução por dinheiro}

Já naquele tempo não se podia traduzir exclusivamente por amor à literatura. 0 prefácio de Justus Wilhelm Zachariä à segunda edição de 1774 dos 
ROOTHAER, R. - Literatura universal: a tradução na época de Goethe

Versuche über den Character und die Werke der besten Italiänischen Dichter [Ensaios sobre a natureza e a obra dos melhores poetas italianos], de Johann Nicolaus Meinhard, oferece-nos uma explicação de como isso pode se dar: “[...] foram necessários dez anos, antes que se pudesse iniciar esta segunda edição [...]. Ele perdeu não apenas a coragem de continuar se dedicando aos italianos, mas também desistiu completamente de seu outro plano maior de tradução, rebaixando-se à classe dos tradutores ordinários que aceitam a primeira proposta de tradução que lhes faça um livreiro, desde que possam ganhar algo com isso."

\subsection{Queixas por parte dos tradutores}

\subsubsection{Tradutores sob pressão de tempo}

Também naquele tempo já se ouvia a queixa de que os prazos para a entrega das traduções eram demasiado exíguos: "No atual estado das coisas, traduções não são nada mais que frutos precoces, que muitas vezes são servidos meio verdes, somente para satisfazer o apetite voraz dos leitores. Servem mais para serem degustadas do que digeridas. Só alcançam sua verdadeira maturidade na segunda edição." (J.G. Gellius em Anmerkungen zum Gebrauche deutscher Kunstrichter [Notas para uso dos críticos de arte alemães], 1762).

\subsubsection{Plágio}

Os tradutores fizeram valer seus direitos, o que não é de surpreender tendo em vista a prática da época de se publicarem múltiplas reimpressões e a tolerância ao plágio. 0 próprio Goethe cometeu esse pecado quando se apropriou dos escritos de outro autor sem prestar o devido esclarecimento. No segundo ato de sua tragédia Clavigo, Goethe incorporou uma tradução bastante fiel das Mémoires de Pierre-Augustin Caron de Beaumarchais e inclusive considerou o procedimento bastante normal, conforme escreveu a um amigo, em 21 de agosto de 1774: "É uma sorte que as Memórias de Beaumarchais, de cet aventurier français, tenham me alegrado e despertado em mim uma energia 
juvenil e romântica e que a sua personalidade e suas façanhas tenham se fundido com personalidades e façanhas em mim e assim se tornado meu Clavigo; pois tive prazer em escrevê-lo, e mais, desafio a lâmina mais afiada a separar do todo apenas as passagens traduzidas sem o lacerar, sem provocar uma ferida mortal (não só à história, mas) à estrutura, à organização vital da peça! [...] Jung não é o primeiro a duvidar que ela seja de minha autoria? Que duvide. Espero um momento oportuno para compor mais uma peça e novamente sem me preocupar se isso poderá comprometer minha reputação ou exaltá-la." "Ainda no mesmo ano, Beaumarchais assistiu a uma apresentação da peça em Augsburg e criticou a maneira como Goethe se apropriara de sua narrativa. É quase certo que, nos nossos dias, ele não teria hesitado em acionar um tribunal para reivindicar seus direitos autorais." (MüLLER 1989: 70-71).

Além disso: "Pode-se até mesmo afirmar que Goethe incorporou adaptações livres em cada uma de suas obras. Sua opereta A Pescadora contém uma canção eslava, originária do povo polábio, ${ }^{3}$ que fora traduzida e registrada por Herder. Goethe a utilizou com alterações mínimas." (ibid.)

Então também não causa surpresa que os tradutores tenham se manifestado contra essa postura, sobretudo quando se trata de incorporar suas traduções com alterações: "Não detenho nenhum monopólio: todos têm o direito de traduzir Shakespeare. E mesmo corrigir meu Shakespeare, qualquer um pode: ou escrevendo à mão nas margens de seu próprio exemplar, ou na forma impressa, em textos críticos, e assim por diante. Mas intrometer-se com correções na minha tradução sem minha permissão expressa, isso ninguém pode [...]. Portanto, diante do atual dilúvio de traduções de Shakespeare, se alguma de minhas versões ficar para a posteridade, espero que seja integralmente de meu próprio punho e que a tradução tenha como título: trad. por Schlegel com plenos direitos." (August Wilhelm Schlegel: carta ao editor Georg Andreas Reimer, final de 1838/início de 1839).

\footnotetext{
${ }^{3}$ Refere-se à etnia eslava residente, durante a Idade Média, à margem esquerda do rio Elba. A língua polábia e seus dialetos extinguiram-se ao fim da Idade Média e restam apenas fragmentos de evidências, especialmente em topônimos. (N. d. T.)
} 
ROOTHAER, R. - Literatura universal: a tradução na época de Goethe

\subsubsection{Reimpressões}

Quando Ludwig Friedrich Vischer lançou no mercado, em 1720, uma tradução alemã do Robinson Crusoe, de Daniel Defoe, nas primeiras semanas saíram nada menos que cinco reimpressões.

Johann Joachim Christoph Bode reagiu às reimpressões de sua tradução de Tom J ones com o anúncio de uma redução no preço dos livros: "Esta obra foi reimpressa logo após a sua publicação; e para compensar pelo menos em parte o prejuízo que sofri, reduzi o preço da edição original para quatro táleres reais da Saxônia até a missa de Páscoa de 1792, e darei um desconto considerável em caso de encomenda de vários exemplares."

Em 1839, saiu uma reimpressão das traduções de Calderón, em Stuttgart, feitas por Johann Diederich Gries e Georg Nicolaus Bärman. Para defender-se, Gries criticou-as com versos satíricos:

Ó brava terra dos suábios

Como está sepultada tua glória

Que fora outrora tão poderosa!

De cada janela agora miram

Copiadores e fantasmas

Que nenhuma lei mais afasta.

\subsection{Tradutores no fogo cruzado da crítica}

A respeito dos tradutores, há críticas em abundância. Muitas delas referem-se a princípios de tradução que ainda discutiremos abaixo, de modo mais detalhado. As palavras dos críticos são, por vezes, bastante venenosas.

O resenhista que, em 1790, na Neue Bibliothek der schönen Wissenschaften und der freyen Künste [Nova Biblioteca das Belas Ciências e das Artes Liberais], diz que "o tradutor alemão nos agracia com um Virgílio nada alemão", atenua sua crítica com uma pergunta: "É possível emitir um juízo diferente sobre uma obra que nega o gênio de nossa língua e a descaracteriza para seguir o modelo romano, que se desvia, sem motivo algum, do uso 
consolidado das palavras e coloca, no lugar das palavras antigas e compreensíveis, outras com marcas recém cunhadas que não são mais expressivas ou significativas que aquelas e até mesmo induzem o leitor a erros? Uma obra que está impregnada de inversões, transições e nexos estranhos, em suma uma obra que nos recorda a todo o momento, não somente pela cor local romana, mas também pela sua expressão e suas locuções, que estamos lendo uma tradução do latim?” - Esse “tradutor alemão” era Johann Heinrich Voss.

A. W. Schlegel parece compartilhar essa crítica sobre J. H. Voss, pois, em sua opinião, este "agraciou o povo alemão com um Homero de pedra, um Aristófanes de couro e um Shakespeare de madeira". J. H. Voss foi notoriamente muito famoso em seu tempo, e suas traduções são lidas até hoje.

O escritor anônimo que traduziu as fábulas de La Fontaine (título: Ein Versuch für Freunde ächter Originalität [Um ensaio para os amigos de verdadeira originalidade], de 1819, em sua grande parte composto de versos brancos, ousou um juízo devastador sobre traduções mais antigas. Ele detectou nas Nachbildungen [imitações criativas] de Friedrich von Hagedorn e Johann Wilhelm Ludwig Gleim “dispersão, tagarelice, inchaço e verborragia completamente desnecessários”. Com relação à tradução rimada de Samuel Heinrich Catel, dos anos de 1791-94, ele escreve: "Sua versificação é correta quanto às sílabas métricas e às rimas, mas sem brilho e sem cor e, em grande parte, fica pior do que a prosa. Sua simplicidade acaba sendo trivialidade, sua imaginação é fria; sua graça, artificial; sua ingenuidade, insípida e sóbria; sua vivacidade, forçada; seu sentimento, superficial e, por isso, raramente está correto. Todas as poesias mais sérias de La Fontaine transformam-se, com ele, em insossos gracejos."

Em suas notas ao prefácio, esse mesmo desconhecido manifestou-se com as seguintes palavras sobre o renomado J. H. Voss: "Visto que Voss, ao estilo de Minellius, ${ }^{4}$ editou recentemente um comentário sequencial [fortlaufend] à

\footnotetext{
${ }^{4}$ No século XVII, Minellius exerceu a função de reitor do Ginásio Erasmus, de Roterdã, que publicava traduções interlineares de obras gregas e romanas para seus estudantes, bem como respectivas explicações e paráfrases (RR).
} 
ROOTHAER, R. - Literatura universal: a tradução na época de Goethe

tradução de Shakespeare por A. W. Schlegel, certamente todos os amigos do bom gosto e da língua alemã desejariam que A. W. Schlegel estivesse disposto a traduzir o Homero de Voss para o alemão e, como Hércules, precipitar-se no Hades e de lá reconduzir à superfície o herói até então relegado às trevas e aos grilhões. - Será verdade que Voss também pretende desgermanizar a Donzela de Orleans, de Voltaire, e A Guerra dos Deuses, de Parny?"

Especialmente incisiva foi a crítica de A. W. Schlegel a ninguém menos do que Friedrich von Schiller, que também atuava como tradutor:

Consolo para um empreendimento difícil.

Sei pouco inglês

E Shakespeare eu mal entendo:

Mas o fiel Eschenburg bem ajuda

A me enveredar por Macbeth.

Sem nada saber de grego,

Fiz Ifigênia falar alemão.

De latim também pouco sabia, Mas meti Virgílio em estrofes.

Macbeth

Encenado

Por Schiller

Para o Teatro da Corte de Weimar.

(Mote de Hamlet)

Macbeth desandou: é uma grande vergonha

Que justamente eu tenha vindo ao mundo para encená-lo.

\subsection{Traduções a partir de línguas orientais}

$\mathrm{Na}$ época de Goethe havia um grande interesse pela literatura oriental. Traduzia-se muito a partir do persa, chinês, árabe e das línguas indianas. Dentre os mais famosos tradutores figurava o barão Joseph de Hammer-Purgstall, que em 1812 fez a tradução, a partir do persa da obra O Divã, de Chams Addîn Muhammad Hafez. ${ }^{5}$ Outros exemplos de traduções estão elencados abaixo.

\footnotetext{
${ }^{5}$ Agradecemos à professora Mona Mohamad Hawi do Departamento de Letras Orientais da USP por ajudar-nos com esta e as outras transliterações dos nomes persas para o português. (N.d.T.)
} 


\subsection{Tradução indireta}

Naturalmente, aqui se trata amiúde de traduções a partir de outras traduções. Foi o que Johann Friedrich Herder fez com Gedanken eines Brahmanen [Pensamentos de um brâmane] de Saadis Golestan e também com outras obras para as quais ele utilizou modelos em inglês, francês ou latim o que, aliás, o título da obra revela claramente: Kalidas: Sakontala oder der entscheidende Ring, ein indisches Schauspiel. Aus den Ursprachen Sanskit und Prakrit ins Englische und aus diesem ins Deutsche übersetzt mit Erläuterungen von Georg Forster [Sacontala ou o anel fatal, um drama indiano. Traduzido do original em sânscrito e prácrito para o inglês e, a partir deste, para o alemão, com comentários de Georg Forster] (1791). ${ }^{6}$

Em 1772, Goethe traduziu a sexta sura do Corão. Ele usou a edição latina de L. Marracius (Leipzig 1721) como texto-fonte. 0 último trabalho de tradução conhecido de Goethe data de 1825, quando traduziu canções populares do grego moderno com o título Neugriechische Liebe-Skolien [Skolias de amor em grego moderno] em que utilizou a coletânea Chants populaires de la Grèce moderne [Canções populares da Grécia moderna] de C. C. Fauriel. (Ambos os exemplos são de MüLleR, 1989, 73 e 81).

Por vezes, isso também ocorreu com outros idiomas. Luise Adelgunde Victoria Gottsched-Kulmus escreveu no prefácio de sua tradução de The Rape of the Lock (1744) [0 rapto da madeixa] de Pope: “[...] contudo trabalhei nisso com receio, visto que eu não dispunha do original, somente de uma tradução francesa em prosa [...]". E em 1745, Johann Heinrich Rüdiger publicou uma tradução reduzida da obra J oseph Andrews [A história das aventuras de J oseph Andrews e seu amigo o Senhor Abraham Adams] $]^{7}$ de Henry Fielding e escreveu na introdução: "queremos [...] declarar publicamente que para nossa tradução tomamos por base meramente a versão francesa dela (i.e., da tradutora, RR)."

\footnotetext{
6 KeLLY, Stuart. O livro dos livros perdidos. Rio de Janeiro: Record, 2007, p. 122. (N.d.T.)

7 FIELDING, Henry. A história das aventuras de J oseph Andrews e seu amigo o Senhor Abraham Adams. Tradução, introdução e notas: Roger Maioli dos Santos. $1^{\text {a }}$ Edição. São Paulo: Ateliê editorial. Editora Unicamp, 2011. (N.d.T.)
} 
ROOTHAER, R. - Literatura universal: a tradução na época de Goethe

\subsection{Conhecimento de idiomas}

Atualmente é muito menos habitual recorrer a uma língua intermediária na tradução. Isso costuma gerar até mesmo rejeição. Naquela época, um tradutor ousou confessar publicamente que não conhecia bem certa língua estrangeira: “[...] meu domínio do espanhol ainda é muito recente e, tendo em vista a insuficiência do meu material de consulta, também bastante imperfeito. E Calderón não é nada fácil." (Johann Dietrich Gries a Johann Georg Rist, 1814). Ou ainda Christian Friedrich Tieck falando sobre sua própria tradução de Dom Quixote em uma carta a Karl Wilhelm Ferdinand Solger, de 1 de setembro de 1815: "Na época, empreendi essa tradução com grande despreparo e sem nenhum material de consulta, com a mais inútil edição, o pior dicionário e depois de muitos anos sem ter lido nada em espanhol".

\subsection{Conhecimento do original e afinidade com o}

\section{autor}

Sabemos que os tradutores devem se familiarizar a fundo com o original, bem como ter estudado intensamente o pensamento do autor: "A partir do exemplo de Ebert (tradutor de Young, RR), nossos tradutores deveriam aprender como estudar um autor antes de se atrever a traduzi-lo. Ele não se contenta em adivinhar grosseiramente o sentido; estuda cada palavra, cada significado em sua completa extensão; vasculha a língua em busca da expressão mais apropriada ao pensamento do original; analisa até que ponto o caráter da sua língua permite traduzir literalmente ou, caso soe estranho ou seja ininteligível, como pode encontrar um modo de falar de igual valor, sem debilitar a força do modelo original; procura até mesmo os trechos paralelos de outros escritores excelentes, que podem fazê-lo perceber o verdadeiro sentido e a verdadeira expressão. (Extraído de uma crítica na Bibliothek der schönen Wissenschaften und der freyen Künste [Nova Biblioteca das Belas Ciências e das Artes Liberais], vol. 9, pp. 271, 1763.) 
Consta algo semelhante em uma resenha anônima à tradução de Karl Wilhelm Ramler de algumas odes de Horácio na Allgemeine Deutsche Bibliothek [Biblioteca geral alemã] (1770): “Esse será um agradável presente aos conhecedores de Horácio, dado por um poeta cuja familiaridade com o romano é conhecida, que não raro o imitou de modo tão primoroso em seus próprios excelentes poemas, e de quem realmente temos uma prova de que sabe amoldar-se ao modo de pensar e, por assim dizer, à forma do gênio de outros escritores, uma qualidade que é indispensável ao tradutor [...]"

0 tradutor desconhecido das fábulas de La Fontaine mencionado no item 1.6 posiciona-se de forma muito crítica a respeito daqueles que traduzem "tudo". Isso não funciona, pois, no caso, o tradutor precisaria ter mais talento do que os autores a serem traduzidos. Como estaria ele em condições de respeitar o que caracteriza o original? "Aquele que quer impor seu próprio estilo ao do original não agrada a ninguém, e o imitador criativo que não sente nenhuma afinidade com o original, que se cuide para não pecar contra o próprio. Sempre me saltou aos olhos como um artista da palavra pode ousar traduzir poetas tão diferentes como Homero, Aristófanes, Virgílio, Ovídio, Tibulo e Shakespeare. Para isso, na verdade, seria necessário possuir mais gênio que todos esses homens juntos. 0 resultado também não nos mostra nada mais do que cadáveres frios e enrijecidos que apenas parecem respirar um pouco de vida quando são iluminados e acalentados com a luz etérea do original. Para quem não tem essa luz a seu alcance, permanecem sem vida e sem sentimento." E então segue a verborragia contra J. H. Voss citada no item 1.6.

J. H. Voss, porém, não é o único que traduz uma série de diferentes autores. Schiller, Goethe, A.W. Schlegel também o fazem e, muitas vezes, com sucesso. Há também os tradutores que se limitam a um gênero específico, como J. Hammer, que trabalha com o idioma persa.

A primeira categoria é de longe mais numerosa do que a segunda, e é legítimo questionar se entre os primeiros encontram-se os piores tradutores. Para a redação de uma boa tradução, necessita-se provavelmente tanto talento literário quanto pesquisa minuciosa e compreensão profunda da fonte. 
ROOTHAER, R. - Literatura universal: a tradução na época de Goethe

\subsection{Valorização do trabalho do tradutor, orgulho do tradutor}

Embora sejam feitas muitas críticas ao tradutor, também é preciso constatar que naquele tempo os trabalhos de tradução eram bastante valorizados, e os tradutores também recebiam muitos elogios. A justificativa talvez seja a boa qualidade das traduções, e ela se deve, por sua vez, ao fato de muitos literatos se dedicarem ao mister, ou (sendo mais atrevido) de o elogio recíproco ser o balcão de negócios do tradutor. É verdade que isso bem pode ter ocorrido - assim como hoje -, mas as críticas muitas vezes virulentas e as discrepâncias acerca dos critérios de tradução contradizem e muito esse argumento.

"O que outrora se passou com Meinhard pode também ser exigido por Bode. Afinal de contas, não se trata de um aprendiz qualquer no ofício da tradução, mas de um virtuoso em sua especialidade, de um mestre há muito tempo respeitado na Alemanha entre seus bons escritores, entre os criadores e enriquecedores de bom gosto da língua, respeitado como o mais feliz transplantador de uma flor viçosa, que, no passado, existia apenas sob o céu britânico, com aquele estilo humorístico, e que ainda será mencionado com veneração, mesmo quando algumas de nossas obras originais mais prezadas há muito houverem afundado no Lete implacável." (Carl August Boettinger, J .J .C. Bode's literarisches Leben [A vida literária de J. J. C. Bode], 1796).

(Em 1796, o tradutor J. N. Meinard foi homenageado por Friedrich Justin Riedel: Denkmal des Herrn Johann Nicolaus Meinhard [Monumento ao sr. J ohann Nicolaus Meinhard]).

J. G. Herder também faz elogios em Briefe zur Beförderung der Humanität [Cartas para o desenvolvimento da humanidade]: “Agradecemos também, portanto, a cada bom tradutor dos bons humoristas britânicos. E todos nós sabemos a quem devemos agradecer, em especial aqui na Alemanha: ao tradutor de Yorick, Sterne, Fielding, Smollet, Goldsmith, Cumberland e outros 
mais. As traduções de Bode das viagens sentimentais, ${ }^{8}$ de Tristram Shandy, Thomas Jones, Humphrey Clinker, o Vigário de Wakefield, o antilhano, ${ }^{9}$ estão nas mãos de todos.

Será que hoje poderíamos imaginar elogios tamanhos a um tradutor? Hoje há prêmios de tradução, mas em muitas obras o nome do tradutor sequer é mencionado, sobretudo quando se trata de textos informativos: isso se deve à enorme demanda desse tipo de tradução e à efemeridade das informações veiculadas, ao fato de a tradução hoje em dia ter se tornado uma atividade preponderantemente não literária que se faz mediante remuneração. Nos tempos de Goethe, os escritores mais renomados gostavam de atuar como tradutores. "[...] posto que quase não há escritor alemão de peso que não tenha feito traduções e delas se orgulha como se tivesse produzido uma obra original [...]" (Carta de Novalis a A. W. Schlegel, 30 de novembro de 1797).

Muitas vezes se ouve falar do grande orgulho de tradutores e traduções: Nekrolog [Elogio fúnebre] de Friedrich Schlichtegroll (1793) sobre J. J. Chr. Bode: "Mestre na grande arte de transplantar para o solo alemão obras estrangeiras do gênio." Ou ainda: "Vê-se nitidamente na tradução de Sófocles por Stollberg o quanto ganhou a arte da tradução na Alemanha nos últimos quinze anos. Se ela fosse ao menos tão boa quanto a tradução de Eurípides por Bothe, já seria de grande valia, por mais que aqui ou ali ainda deixe a desejar. Mas usar métricas horácicas para coros trágicos realmente não passa de um refúgio um tanto precário. É melhor refazê-los a partir do zero! E mesmo assim, para sua época o trabalho de Stollberg é digno de todas as honras. Agora nós alemães podemos estar orgulhosos de termos as melhores traduções dentre todas as nações. (Friedrich Solger, Nachgelassene Schriften [Escritos Póstumos], 1800).

\footnotetext{
8 Referência ao romance A Sentimental J ourney Through France And Italy [Uma viagem sentimental através da França e da Itália], de Laurence STERNE (1768). Tradução de Bernardina da Silveira Pinheiro, Rio de Janeiro: Nova Fronteira, 2002. (N.d.T.)

9 Referência à peça cômica The West Indian [O antilhano], de Richard CumberLand (1771). (N.d.T.)
} 
ROOTHAER, R. - Literatura universal: a tradução na época de Goethe

Também a Allgemeine deutsche Real-Enzyklopädie für die gebildeten Stände von Brockhaus [Real enciclopédia geral alemã para as classes cultas, de Brockhaus] faz coro com os elogios em 1820: "Dentre os alemães, os primeiros a abrir as portas para uma forma melhor de traduzir foram Voss, Schlegel e Gries [...] Nenhuma das línguas mais novas se aproxima tanto das antigas, da grega e da romana, em termos de caráter, como a alemã; nenhuma está em condições de apropriar-se da métrica das antigas. Por isso, também, nenhuma língua pode apresentar melhores traduções dos poetas antigos. Homero traduzido por Voss, Calderón por Schlegel, Torquato Tasso e Calderón por Gries são magníficas cópias para aquele a quem o prazer da obra original está fora de alcance."

\subsection{Utilidade das traduções}

Vem de Goethe uma bela observação sobre a valorização e a utilidade das traduções: "Cada literatura acaba se enfastiando quando não é renovada por meio de participações estrangeiras" (1828). Essa observação é o resultado de uma longa experiência de vida, de trabalhos próprios de tradução e do conhecimento de literatura estrangeira. Nesse contexto, Goethe fala de "Weltlitteratur" [literatura universal] (Diário, 15 de janeiro de 1827) e diz que traduções difundem a literatura e as ideias por todo o mundo como "mensageiros expressos [...] a partir de todos os rincões do mundo".

A valorização do ofício da tradução e até mesmo o orgulho nacional ressoam nas cartas supracitadas (1.11) de Novalis para A. W. Schlegel por ocasião da tradução de Shakespeare feita por este último: os tradutores possibilitam ao povo o acesso à literatura universal. Os alemães são os melhores nesse mister. Eles são os verdadeiros cosmopolitas: "Por mais que nós alemães traduzamos, por mais nacional que seja essa propensão à tradução - uma vez que praticamente não há escritor alemão de peso que não tenha feito traduções e delas se orgulhe como se tivesse produzido uma obra original - tanto mais parece que não há área de maior desconhecimento do que a tradução. Entre 
nós, a tradução pode se tornar arte e ciência. Seu Shakespeare é um cânone apreciável para os observadores científicos. Somos a única nação além dos romanos que sente tão irresistivelmente o impulso à tradução, e a este devese parte tão significativa de sua formação. [...] Esse impulso é uma indicação do caráter muito elevado e autêntico do povo alemão. A germanidade é cosmopolitismo misturado com a mais expressiva individualidade. Somente para nós as traduções significaram ampliações. [...] Traduz-se por amor à beleza e à literatura da terra natal. Traduzir é tão bom fazer poético quanto compor uma obra própria - até mais difícil e mais rara. No final das contas, toda poesia é tradução. Estou convencido de que agora o Shakespeare alemão é melhor que o inglês."

Nesse contexto, Goethe faz uma comparação em certa medida frívola: "Tradutores podem ser vistos como alcoviteiros diligentes que nos recomendam uma beldade semiencoberta como a mais digna de nossa devoção: eles provocam uma inclinação irresistível em direção ao original." (Máximas e Reflexões, $n^{\circ}$ 299).

Através das traduções não só podemos conhecer a literatura e o espírito de povos estrangeiros. Também há de ocorrer uma "naturalização" na cultura alemã. Porém, em relação a essa germanização, deve ser observada a seguinte diferença: se, de um lado, a intenção é fazer desaparecer tudo que for estrangeiro ou, de outro, se as marcas estrangeiras devem ser preservadas para serem incorporadas na cultura alemã. (sobre o assunto vide item II, passim)

\subsection{Os tradutores enriquecem a língua de chegada}

Além disso, os tradutores enriquecem a língua alemã: " $O$ ato de traduzir, e sobretudo a de literatura, é antes de tudo um dos trabalhos mais necessários em uma literatura, em parte para [...] familiarizar aquele que não domina um idioma com formas da arte e da humanidade que, de outra maneira, the permaneceriam totalmente desconhecidas, mas também, e de maneira primorosa, para a expansão da importância e da capacidade de expressão da própria língua. Pois se trata de uma maravilhosa propriedade de todas as línguas 
ROOTHAER, R. - Literatura universal: a tradução na época de Goethe

que elas primeiramente sirvam ao uso ordinário da vida, podendo depois, por meio do espírito da nação que a elabora, elevar-se até o infinito na direção de um uso mais elevado e sempre mais variado [...]. Para citar apenas um exemplo: quanto não ganhou a língua alemã desde que passou a imitar os metros gregos! [...]" (Prefácio à tradução do Agamêmnon, de Ésquilo, por Wilhelm von Humboldt, 1816).

Chr. F. Tieck elogia a tradução dos dramas de Shakespeare por A. W. Schlegel com entusiasmo (Prefácio à edição "melhorada” pelo próprio Tieck (! - vide item 1.5, edições) (1833): “[...] sua maestria é tão grande que cada expressão ou forma nova que ele experimenta pode ser imitada com toda ousadia, pois todas essas inovações constituem justamente os tantos modelos exemplares com os quais nossa língua tem sido enriquecida de maneira extraordinária."

"Talvez alguém queira opinar sobre alguns trechos em que a fidelidade medrosa tenha sido excessiva e adquirida a um preço alto demais através de algumas expressões totalmente imitadas dos persas. Já que a língua alemã se apropriou com sucesso de tantos adereços da grega e da romana, menor será o estranhamento causado por alguns brincos emprestados da irmã da persa." (J. von Hammer, prefácio a O Divã, de Chams Addîn Muhammad Hafez, 1812-13).

Como exemplo concreto do enriquecimento da língua com a palavra alemã empfindsam [sensível, sentimental] citamos J. J. Chr. Bode em seu Der Übersetzer an den Leser [0 tradutor ao leitor] na tradução de A Sentimental J ourney through France and Italy [Uma viagem sentimental pela França e Itália], de Laurence Sterne: "Eis o que tenho a dizer sobre o adjetivo "empfindsam" para traduzir o inglês "sentimental". De início eu havia traduzido o termo por "sittlich" [decente], mas também havia proposto outras expressões, mesmo paráfrases. Contudo, foi meu amigo que cunhou a palavra “empfindsam” (este amigo era Gotthold Ephraim Lessing, RR). “Aqui estão suas próprias palavras: [...] Note portanto, que "sentimental" é uma palavra nova. Sterne pôde se permitir formar uma palavra nova; então o mesmo deve valer para o seu tradutor. Os ingleses não tinham nenhum adjetivo derivado de 
"sentiment"; nós tínhamos mais do que um, derivado de "Empfindung". Empfindlich [sensível], empfindbar [passivel de sentimento], empfindungsreich [cheio de sentimentos]: mas cada um deles significa algo diferente. Arrisquese a usar "empfindsam"! Se chamamos de cansativa [mühsam] ${ }^{10}$ uma viagem na qual há muito cansaço: então podemos chamar de sentimental uma viagem na qual houve muito sentimento."

\subsection{Tradução Repetida}

A época de Goethe é, como já foi dito, especialmente rica em tradutores e traduções; mas, na verdade, muitas vezes trata-se de adaptações e revisões. Ninguém parece duvidar de que é possível fazer boas traduções que representam a fonte com fidelidade tanto na forma quanto no conteúdo e que lhe correspondem suficientemente. No entanto, com bastante frequência aparecem novas traduções dos mesmo escritores. É o que ocorre, por exemplo, com obras de Horácio, Virgílio, Aristófanes e ainda vários outros autores da antiguidade, bem como com obras das literaturas inglesa e francesa mais antigas e contemporâneas.

O ponto alto do trabalho de tradução é, sem dúvida, alcançado com Shakespeare. Primeiro foram traduzidas algumas peças de teatro isoladas: J úlio César por Caspar Wilhelm von Borck (1741), Romeu e J ulieta por Simon Grynaus (1758). Depois vieram a lume as obras teatrais reunidas: Shakespeare: Obras Teatrais por Chr. M. Wieland (1762-1766), Peças de William Shakespeare por J. J. Eschenburg (1775), Obras dramáticas de William Shakespeare por A. W. Schlegel (1797) e, sob o mesmo título, mas acrescido dos dizeres "traduzido por August Wilhelm von Schlegel, complementado e explicado por Ludwig Tieck" (1825-33) (vide o protesto de Schlegel no item 1.5). Nesse ínterim, saíram ainda Peças de Shakespeare, traduzidas por J. H. Voss e seus filhos (1818-1829). Além disso, algumas peças isoladas para o palco foram traduzidas e/ou revisadas por Gottfried August Bürger, Schiller, Goethe, entre outros.

\footnotetext{
${ }^{10}$ Adjetivo formado a partir do substantivo Mühe [esforço] e o sufixo -sam.
} 
ROOTHAER, R. - Literatura universal: a tradução na época de Goethe

Deve haver motivos mais profundos para a mesma obra ter sido traduzida repetidas vezes. Talvez o cerne da explicação seja que as concepções sobre a melhor maneira de traduzir e os objetivos que se pretende alcançar estejam sujeitos a constantes mudanças. Isso indica que reina a opinião de que (ainda) não se alcançou uma perfeição na área da tradução. Muitos iniciados talvez duvidem da viabilidade de uma perfeição, mas não por isso querem deixar de tentar um novo experimento.

\subsection{Traduzir é possível?}

Arthur Schopenhauer (Obras Completas, Livro 5, Stuttgart, Frankfurt am Main, 1965, pp. 667) - como era de se esperar - hesita no que concerne à tradução: "Aí reside o que é necessariamente insuficiente em todas as traduções. Quase nunca se consegue transpor um período característico, marcante e significativo de uma língua para outra, de modo que cause exata e inteiramente o mesmo efeito. - Não se pode traduzir poesia, senão apenas repoetizar, o que é sempre precário. Até mesmo na prosa simples a melhor das traduções poderá, na melhor das hipóteses, representar para o original aquilo que a transposição para outra tonalidade representa para uma determinada peça musical. Os entendidos em música saberão do que se trata. - Por isso, toda tradução permanece morta e seu estilo, forçado, rígido e artificial, mas ela se liberta, isto é, contenta-se com um mais ou menos, e assim se torna falsa. Uma biblioteca de traduções se iguala a uma galeria de quadros inteiramente composta por réplicas. $\mathrm{E}$ as traduções de autores da antiguidade então são um mero substituto deles, como o café de chicória em comparação com o café de verdade." 


\section{Tradução fiel, adequação, adaptação}

Alguns tradutores reclamam o direito de fazer adequações e adaptações. Outros, em compensação, prestam juramento solene em favor da "fidelidade". Ninguém, entretanto, é capaz de definir o que seria exatamente essa "fidelidade", pois é sabido que isso não pode significar igualdade. Na tentativa de evitar esse problema, introduziu-se o conceito de "equivalência"; mas, na verdade, ele suscita a mesma objeção: é demasiado vago. A partir das citações a seguir, ficará evidente que os mesmos argumentos, contra e a favor da fidelidade, foram invocados naquele período, e que ninguém empreendeu a tentativa de definir tais conceitos. E vai mais além: muitos tradutores, dentre eles também Goethe e Chr. M. Wieland, argumentam a favor da fidelidade, da adequação ou da adaptação de acordo com o caso em questão.

Em sua introdução ao segundo volume das Volkslieder [Canções Populares], J. G. Herder diz que o mais difícil na tradução é "transpor o tom da melodia de uma língua estrangeira”, sendo que às vezes não há outro meio senão “apreender fielmente a canção, assim como ela ressoa em nós, e, assim preservada, reproduzi-la.". Portanto, a fidelidade só é possível de forma restrita e consiste principalmente na reprodução correta da impressão evocada.

A opinião de Joseph Meyer, que chama a sua própria obra de uma adequação livre do teatro shakespeariano (1824), alinha-se, em certa medida, a essa visão; mas suas próprias palavras descrevem seu pensamento de maneira mais exata: “O gênio de um autor pertence a todas as épocas, a todos os povos, mas a forma pertence apenas àquela língua, àquele tempo e àquele povo em meio ao qual ele escreve. Querer transplantá-la para outra língua, para outro tempo e para outro povo será tão malogrado quanto tentar introduzir os pomares de limoeiros italianos em nossos Alpes ou tanto quanto querer sugerir a nossos conterrâneos o tom da conversação, os costumes e hábitos espanhóis dos tempos de Calderón.” Essa postura aproxima-se muito daquela que, como 
ROOTHAER, R. - Literatura universal: a tradução na época de Goethe

Schopenhauer, considera que a tradução é impossível - ao menos a tradução expressiva.

\subsection{Motivos para a adequação ou adaptação}

De acordo com Wilhelm Christhelf Siegmund Mylius precisamos recorrer à germanização para tornar acessível o Kandide oder die beste Welt [Cândido ou o otimismo], de Voltaire (Prefácio). Isso nos dá o direito de, "vez ou outra, inocular um grãozinho em um tronco que se gabe de ter crescido em solo alemão. Ou seja, de vez em quando, da maneira mais modesta, acrescentar à trama um traço mínimo, por meio do qual o todo tomasse mais ares de produto nacional.". E acrescenta: "aqui fomos forçados a substituir por referências envolvendo autores e escritos alemães aqueles traços de sátira sobre obras e homens que não fossem plenamente conhecidos nem mesmo do mais fervoroso amante da literatura francesa, ou que, na maioria dos casos, the fossem completamente desconhecidos".

Existem, portanto, bastantes tradutores que consideram aceitáveis alterações intencionais em relação ao original. Por ocasião de sua tradução de Macbeth, Gottfried August Bürger explicou: "à parte da linguagem, da forma e de algumas omissões, eu acrescentei uma cena nova aqui e ali. Goekingk, para quem [...] a recitei, estremeceu profundamente diante de uma cena que apresentava a morte de Lady Macbeth. Pois, em Shakespeare, ela perece tão rapidamente. Fi-la agonizar mais um pouco, de modo a causar arrepios." (Carta a Heinrich Christian Boie, 22 de janeiro de 1787).

Em Shakespeare als Theaterdichter [Shakespeare como poeta dramático], publicado no periódico Ueber Kunst und Alterthum [Sobre Arte e Antiguidade], v. 5, 1826 (texto de 1816), Goethe explica: “Ora, há muitos anos tem-se introduzido furtivamente na Alemanha o preconceito de que Shakespeare deve ser representado palavra por palavra nos palcos alemães, por mais que os atores e espectadores se asfixiem com elas. As tentativas, 
motivadas por uma tradução virtuosa e exata, não vingam em lugar nenhum [...]".

Alguns tradutores acham que a adequação e a adaptação podem produzir um texto melhor do que o original: "No que diz respeito à minha germanização, esforcei-me [...] - não hei de negar - por não apenas alcançar o original, mas também, quando foi possível, superá-lo. Era o dever de um alemão explorar ao máximo suas riquezas. Racine fez o que pôde, mas seu gênio sucumbiu sob o fardo de sua língua pouco poética. Se em meus esforços não fui malsucedido, não o atribuo a meus méritos e minha dignidade, mas sim à armadura com a qual lutei: minha métrica e minha língua." (Carl Friedrich Cramer, Prefácio à tradução de Athalie, 1786)

\subsubsection{Distância temporal e espacial ou a alteridade}

A maioria dos tradutores argumenta contra a adaptação proposital e a adequação, mas, de um caso para outro, acabam descobrindo motivos para realizar modificações. É o que sempre se diz: a distância de tempo e espaço exige modificações, principalmente no caso de autores clássicos ou orientais. Observe-se, acima, o já mencionado trecho de J. Meyer no item II: “[...] a forma pertence apenas àquela língua, àquele tempo e àquele povo em meio ao qual que ele escreve".

Joseph von Hammer (1812-13) realizou a tradução de O Divã, de Hafez, a partir do persa, e disse em seu prefácio: "O objetivo último a que esta tradução almeja é a fidelidade máxima não apenas na expressão e na imagem, mas também no ritmo e na construção das estrofes. Onde foi possível reproduzir verso a verso, assim aconteceu, e a liberdade nunca excedeu à da transformação de dísticos em quartetos".

Joseph Görres, que traduziu Das Heldenbuch von Iran [0 livro de heróis do Irã, extraído do Shah Nameh, de Firdus] (1820), expressa claramente que os motivos de sua tradução livre devem-se à alteridade do texto: "Naquele momento, em respeito ao conteúdo dessas narrativas, orientei-me pelo princípio fundamental de não ignorar nada que, de alguma forma, fosse 
ROOTHAER, R. - Literatura universal: a tradução na época de Goethe

essencial; porém, em relação à forma, procurei sacrificar o menos possível a beleza característica e poética da obra tanto quanto o permitiu a abordagem prosaica [...]. Fazendo uso dessa liberdade, o editor primeiramente optou por uma linguagem que, por meio das cores e da atitude, se aproximasse da antiga épica dos bons tempos, ao limite do que admitia o nosso ouvido - dotado de outra afinação - e a essencialmente mudada disposição das palavras. Além disso, ele precisou limitar aquela amplitude épica e encurtar aquela rica indumentária, partida por muitos vincos, que pode assegurar por si só a dignidade do épico e, ao mesmo tempo, velar e revelar seus movimentos comedidos".

No prefácio a Die Verwandlung des Ebu Seid von Seru'g oder Die Maka'men des Hari'ri in freier Nachbildung ${ }^{11}$ [As transformações de Abu Zayd Al-Sarruji ou Al-Maqamat de Hariri em imitação criativa livre], de autoria de Friedrich Rückert (1826), podemos ler: "Meu trabalho não se dá como tradução, mas como uma imitação criativa [Nachbildung]. Os princípios a partir dos quais Homero e Shakespeare são germanizados, no atual estado da arte, mal podem ser aplicados a um poeta árabe. Para tanto, é necessário um parentesco mais próximo ou uma apropriação mais profunda de um círculo cultural estrangeiro; isso nos dá motivo para nos orgulharmos muito mais em relação ao Oriente do que o fizemos até agora. Espero que ainda chegue o tempo em que as obras maiores do Oriente possam ser inseridas na nossa língua, receptiva a qualquer expansão, por meio de uma transposição fiel." (Al-Maqamat é uma narrativa curta; a obra aqui mencionada é uma coletânea dessas narrativas sobre um mesmo tema)

A distância temporal e espacial é também um motivo para adequar, ao menos em relação à forma, textos informativos, obras filosóficas e argumentativas, nas quais o conteúdo detém uma posição prioritária. Em seu prefácio à tradução da Ethica, de Aristóteles, Chr. Garve ressalta a diferença

\footnotetext{
${ }^{11}$ Al-Maqamat significa "as sessões". O nome completo do autor é Al-Qasim Ibn Ali Al-Hariri. Agradecemos à professora Mona Mohamad Hawi do Departamento de Letras Orientais da USP por ajudar-nos com a tradução.
} 
temporal entre o original e a tradução, e a prioridade do significado sobre a forma. "Questionei-me sobre como eu gostaria de ser traduzido daqui a dois mil anos [...] e minha resposta foi que, quanto maior fosse a distância entre mim e as pessoas daquele tempo futuro, entre minha língua e a delas, tanto mais disposto eu estaria a conceder liberdade a meu tradutor para empreender todas as alterações em minha linguagem para tornar meus pensamentos mais claros a seus contemporâneos".

A partir das citações acima, torna-se evidente que o aspecto da alteridade de um texto é motivo para os tradutores colocarem o conteúdo em um patamar mais elevado que a forma. Muitas vezes, eles nutrem a esperança de que mais tarde também seja possível contemplar os aspectos formais originais. E mesmo um homem como o próprio Goethe fortaleceu essa esperança. À guisa de comparação, vejam-se também as citações no item 2.1.3.

\subsubsection{Problemas linguísticos}

Outra fonte de adequações e adaptações inevitáveis é a língua. Ela nunca se iguala à língua do original. Por fidelidade, como forma linguística, só podemos entender a chamada equivalência: formas de expressão e orações são transpostas e modificadas sintática e estruturalmente segundo os padrões da língua de chegada. A. W. Schlegel dá o seguinte conselho em relação à tradução do Dom Quixote, feita por L. Tieck: “Os muitos particípios causar-lhe-ão alguns apuros, sou da opinião de que, na maioria dos casos, eles devam ser desfeitos em orações diretas." (Carta de 11 de dezembro de 1797). A sentença "tão fiel quanto possível, tão livre quanto necessário" resume a questão, ou, como diz Schopenhauer, (vide item 1.14): uma tradução é a transposição de uma partitura para outra tonalidade.

Além disso, muitas vezes os jogos de palavras, as lacunas no vocabulário e as conotações incongruentes oferecem grandes dificuldades.

\subsubsection{Conotações}


ROOTHAER, R. - Literatura universal: a tradução na época de Goethe

Friedrich Schulz, que traduziu as Réflexions ou sentences et maximes morales [Reflexões ou sentenças e máximas morais], de François de La Rochefoucauld, escreve sobre esse aspecto ressaltando a dificuldade de encontrar boas soluções enquanto se traduz: "Se dele não temos uma boa tradução, deve-se ao fato de que é difícil fazer uma boa tradução; e é difícil porque nossa língua simplesmente não conhece várias palavras ou porque as conhece com outro valor ou outra definição que as que precisaríamos para traduzir, palavra por palavra, um autor dessa categoria, de maneira pontualmente apropriada e exaustiva. Tomemos as palavras francesas goût, habile, sentiment, délicatesse, lumière, raison, esprit, profession, bonté, mine, intérêt, humeur, passion, vertu, opinion, mal, crime, défaut, gloire, sévérité, finesse e outras, e coloquemos ao lado nossas palavras claramente delineadas: Geschmack, geschickt, Gefühl, Zartheit, Licht, Vernunft, Geist, etc. e vejamos se, diante de toda o rigor filosófico dessas palavras, não tenhamos dito alguma insensatez, que ainda mais se agrava à medida que, a todo instante, varia o significado da expressão francesa."

\subsubsection{Referências}

Christoph Martin Wieland justifica suas adequações nas Theatralische Werke [Obras Teatrais] (1766), de Shakespeare, transpostas em prosa, da seguinte maneira: "Aqui seguem no original (The Two Gentlemen of Verona [Os dois cavalheiros de Verona], vide item 1.1, RR) várias falas que consistem apenas em trocadilhos gramaticais e que, portanto, não fariam sentido algum na tradução. Seu conteúdo consiste em máximas cotidianas e triviais contra o amor, às quais Proteu não sabe responder de outra maneira que não seja a dos vazios jogos de palavras." (Tradução em prosa, 1766).

Alguns motivos, alguns deles morais (sobre o tema, vide item 2.1.4), para a realização de adequações são mencionadas no seguinte texto: "Para o leitor alemão, a tradução de Tom Jones, feita pelo senhor conselheiro Bode, de Weimar, é praticamente um original. As belezas que são atraentes a todas as nações foram transpostas pelo senhor tradutor com muita destreza; passagens 
que só poderiam ser compreensíveis aos ingleses foram alteradas no espírito de Fielding; trechos que ofendem o gosto refinado foram sutilmente esmaecidos, outros trechos foram reforçados para não perderem em efeito; referências estrangeiras a costumes e acontecimentos trocados por aqueles ocorridos em nossa pátria [...]." (Nota de Georg Joachim Göschen sobre a tradução de Tom J ones, 1792).

\subsubsection{Questões estilísticas}

No que diz respeito ao estilo, aspira-se por uma congruência aceitável entre a língua de partida e a de chegada. A crítica que Dietrich Wilhelm Soltau teve de digerir sobre sua tradução do Dom Quixote (1800) mostra que isso não é sempre de todo fácil: "Distinguem-se muito bem no Dom Quixote as passagens em que a linguagem da época de Cervantes é nova e cheia de frescor e aquelas que remetem à forma antiquada dos livros de cavalaria, nas falas do herói ou daqueles que assumem seu tom. Visto que o mais importante de uma adaptação poética é preservar para nós o máximo possível do mundo em que a representação do poeta está ambientado, o tradutor também deverá evitar naquelas primeiras passagens tudo aquilo que suscite em demasia as visões e os costumes de nosso tempo; nas últimas, entretanto, ele também deverá imitar aquele tom solene da antiguidade. Mas o senhor $\mathrm{S}$. não tem noção alguma de tudo isso." (A. W. Schlegel, Athenaeum, v. 3, 1800).

A mesma crítica ressoa em uma contribuição de Johann Gottwerth Müller von Itzehoe a respeito de diversas traduções de Tom J ones. Ele louva a tradução mais antiga, de Matthias Arnold Wodarch, pelos seguintes motivos: "Em todos os romances previamente escritos em alemão ou traduzidos para esse idioma, [...] as pessoas não falavam como costumavam falar na vida comum, mas na linguagem literária". Os autores não conheciam a arte de permitir que cada pessoa falasse em sua própria linguagem, mas "essa tradução mais antiga de Tom J ones, paralelamente a uma miríade de erros, tem o mérito de ser 0 primeiro livro em alemão em que a dama de companhia fala numa outra 
ROOTHAER, R. - Literatura universal: a tradução na época de Goethe

linguagem que a donzela, e o impertinente fidalgo do campo pode, por seu tom, ser diretamente distinguido de um homem da nobreza."

Por outro lado, considera-se normal que haja desvios de estilo em traduções a partir de línguas não muito aparentadas ao alemão. Mais uma vez, é válido o trecho citado no item 2.1.1 do prefácio à adaptação de J. Görres de Das Heldenbuch von Iran [O livro de heróis do Irã]. Görres explica ter optado "por uma linguagem que, por meio das cores e da atitude, se aproximasse da antiga épica dos bons tempos, ao limite do que admitia o nosso ouvido - dotado de outra afinação - e a essencialmente mudada disposição das palavras."

\subsubsection{Poesia e prosa}

\subsubsection{Tradução de versos em prosa}

A obra que acaba de ser mencionada acima transforma versos em prosa - e não é um caso isolado. 0 próprio Goethe era da opinião de que o melhor método para aproximar uma obra desconhecida do leitor alemão seria primeiramente transformá-la em prosa, para que o leitor se familiarizasse com o conteúdo estrangeiro, e só então chegar a uma tradução fiel que correspondesse verdadeiramente ao original, por meio de uma reelaboração em versos. Esse procedimento em etapas deveria permitir que a obra tivesse $o$ mesmo efeito que uma obra da literatura local.

Observamos a mesma coisa na seguinte citação de Goethe, extraída de Dichtung und Wahrheit [Poesia e Verdade], Livro 11, 1814: "Reverencio tanto o ritmo quanto a rima; somente a partir deles é que a poesia se torna poesia. Mas aquilo que exerce verdadeiramente uma ação essencial e profunda, aquilo que realmente forma e cultiva, é aquilo que resta do poeta quando traduzido em prosa: subsiste então o puro e completo conteúdo que, quando está ausente, uma exterioridade brilhante tantas vezes procura aparentar e, quanto está presente, esconde. [...] Por isso pergunto se não conviria fazer primeiro uma tradução em prosa dos poemas de Homero; [...]". 
F. Rückert (1826), citado no item 2.1.1, apresenta a seguinte reflexão: "Espero que ainda chegue o tempo em que as obras maiores do Oriente possam ser inseridas na nossa língua, receptiva a qualquer expansão, por meio de uma transposição fiel."

No prefácio a Des Herrn Moliere sämmtliche Lustspiele [Comédias completas do sr. Moliere] (1752), Friedrich Samuel Bierling justifica sua adaptação em prosa: "Molière escreveu aproximadamente metade de suas comédias em versos; traduzimo-las todas num discurso livre [...] seus versos nunca foram considerados um grande modelo. Pelo contrário, à fama de Molière é preciso dizer que por todo esse tempo ele se tem mantido dentro dos limites da escrita cômica, e jamais voou muito alto com suas expressões e seus pensamentos. E isso é um tanto conveniente para o tradutor prosaico."

Em 1777 foram publicados os Pindars Olympische Siegshymnen verdeutscht von Friedrich Gedike [Os hinos olímpicos de Píndaro sobre a vitória traduzidos para o alemão por Friedrich Gedike], com o seguinte comentário do tradutor: "Quem, além disso, está pouco familiarizado com a métrica pindárica [...] admitirá que sua imitação criativa [Nachbildung] da mesma está sujeita a dificuldades muito maiores do que a de Horácio [...]. Por isso, me pareceu melhor escolher a prosa e fazê-la o mais regular possível. Talvez devido a essa regularidade alguns a achem demasiadamente monótona, com o uso frequente de hexâmetros e pentâmetros. Mas justamente por meio disso procurei tornar minha prosa ainda mais próxima da métrica. Seria a recorrente regularidade um sinal de beleza na tradução métrica, mas um erro na prosaica?"

No anúncio da publicação de Des Publius Ovidius Naso Verwandlungen [Metamorfoses, de Públio Ovídio Naso], traduzido por August Rode (1791), consta que ele pretendia "manter as cores autênticas assim como não mutilar o texto com reduções e não o diluir com paráfrases." Por isso, "ele não quis submeter-se à imposição de uma métrica e preferiu escolher uma prosa poética para sua tradução."

"I chose to attempt it in prose rather than in verse, that I might render Your thoughts, if possible, in all their original energy [...]" (Carta de Johann 
ROOTHAER, R. - Literatura universal: a tradução na época de Goethe

Arnold Ebert a E. Young, por ocasião de sua tradução de The Complaint: or Night Thoughts On Life, Death and Immortality [A reclamação: ou pensamentos noturnos sobre a vida, a morte e a imortalidade], por volta de 1769).

\subsubsection{Adequação à forma do verso}

Homero foi traduzido, em diferentes momentos, em prosa (Friedrich Gottlieb Klopstock), em pentâmetros iâmbicos (G. A. Bürger), hexâmetros (Friedrich Leopold Graf zu Stolberg) ou em outras métricas. À época de Goethe, averiguou-se a fundo qual métrica seria considerada a melhor para a tradução. É possível manter o verso original? É necessário fazê-lo? Quais seriam as possíveis alternativas?

Alguns consideram que podem utilizar uma métrica correspondente (à sua própria época). No prefácio às Elegien des Propertius [Elegias de Propércio], o tradutor, Friedrich Karl von Strombeck (1822), escreveu: “Há vinte anos [...], a arte de imitar criativamente [nachbilden] a medida do verso dos antigos tem feito grandes progressos, em especial pelos méritos imortais de Johann Heinrich Voss [...]. Entretanto, visto que deve ser permitido a todo escritor viver conforme suas convicções e, eu ainda diria, preservar seu próprio estilo [...], não hão de tomar-me por teimoso ou negligente por eu não me ter arriscado com construções na língua alemã que artistas da versificação mais audaciosos e mais famosos estimam poder ousar [...]. Desejo que meus versos também sejam lidos por homens e mulheres com formação, mas não eruditos (que Propércio fique longe das moças); e para que desfrutem totalmente de um poema, este deverá estar, quanto à roupagem dos pensamentos em palavras, escrito em alemão, sempre quando isso for permitido pelo elemento estrangeiro de seu conteúdo."

Em 1786 vem a lume a tradução de Chr. M. Wieland das sátiras de Horácio. 0 tradutor defende a escolha de sua métrica poética da seguinte maneira: "Dois foram os motivos para preferir o metro iâmbico ao hexâmetro e cada um por si já seria suficiente. 0 primeiro é a preocupação justificada de, num período de mais de vinte e cinco anos, haver-se praticamente 
desaprendido a arte de fazer hexâmetros alemães [...]." O segundo é que, "ao menos aos meus ouvidos, o iambo livre parece-me mais apto a dar ao leitor uma noção de leveza, naturalidade e desprendimento dos hexâmetros de Horácio, muitas vezes arduamente conquistados, e para produzir nos ouvidos alemães aproximadamente o mesmo efeito que os versos originais produziam nos latinos".

F. Schiller traduziu em oitavas uma parte da Eneida, de Virgílio e comentou o assunto numa carta a Christian Gottfried Körner, em 10 de abril de 1791: “Creio que acharás que Virgílio, destarte traduzido, é uma leitura agradável. Mas é quase um trabalho original, não apenas porque o original latino precisou ser novamente dividido, a fim de obter para cada estrofe um pequeno todo, mas também porque é absolutamente necessário restituir ao poeta, por um lado, aquilo que inevitavelmente the escapou pelo outro."

Mas Schiller não era tão consistente em suas opiniões, pois, quando ele e Goethe quiseram introduzir peças francesas em seu repertório do Weimarer Theater [Teatro de Weimar], veio à tona a questão sobre a necessidade ou não de preservar os versos alexandrinos dos autores franceses clássicos. Ele comenta o assunto numa carta a Goethe, em 15 de outubro de 1799: "A característica do verso alexandrino de separar-se em duas metades iguais, e a natureza da rima, de fazer de dois alexandrinos um dístico, definem não apenas toda a linguagem, mas também todo o espírito interno dessas peças, o temperamento, as mentalidades e o comportamento das pessoas. Dessa forma, tudo se apresenta sob a regra da oposição e, assim como o violino do menestrel dita o movimento dos dançarinos, também a natureza articulada do verso alexandrino determina os movimentos da mente e os pensamentos. A razão é constantemente exigida e cada sentimento, cada pensamento é forçado a se adequar a essa forma, tal como na cama de Procrusto. Ora, visto que com a eliminação da rima alexandrina perde-se toda a base sobre a qual essas peças foram erigidas, restam apenas as ruínas. Não se apreende mais o efeito, pois cessou de existir a causa." 
ROOTHAER, R. - Literatura universal: a tradução na época de Goethe

J. H. Voss esforçou-se por ser tão fiel à forma e ao conteúdo quanto possível. Ele defendia o emprego dos hexâmetros; o amante das artes "perceberá que, acima de tudo, o hexâmetro alemão aspira a imitar ou quase substituir a divisão do latino em membros e articulações, seus pés métricos ligeiros, laboriosos e vigorosos, os fraseados e as entradas firmes, ternas e fugidias, a multiplicidade dos desfechos e das transições, e, na medida em que possa ocorrer, também a mistura de sons variados e significativos."

Christian Ludwig Neuffer escreve em seu prefácio a Virgils Aeneis im Versmaass der Urschrift [A Eneida de Virgílio na métrica do original] (1816): "A magia singular com que Virgílio cativa de maneira tão irresistível está em seu verso. Quem o privar dos versos, também tolherá uma parte essencial de sua beleza. Então quem não estiver à altura dos versos de Virgílio, também não poderá traduzir o poeta [...]." Mas é preciso evitar expressar-se de maneira afetada e sombria, pois "seguir como uma sombra os passos do autor romano, com temerária postura servil, significa sacrificar o gênio alemão em favor do romano; espremer cada verso exatamente num verso novo significa estirar o romano livre na cama de tortura." (Esta última referência posiciona-se claramente contra o método de J. H. Voss).

Versos em rima são traduzidos por versos rimados, mas, às vezes, também por versos sem rimas; versos brancos ficam sem rimas na tradução. Entretanto, J. Chr. Gottsched preparou a tradução de Brief an die Pisonen [Carta aos Pisões] (a chamada Arte Poética) de Horácio em versos alexandrinos rimados. O problema da tradução de versos continua sendo polêmico. $\mathrm{Na}$ maioria das vezes, uma tradução em prosa, nos moldes de Goethe, é rejeitada por ser apenas uma solução bastante provisória. Mas sempre se aceita que a solução ideal seria preservar a forma do verso, a métrica e o ritmo, a sonoridade e a rima, e o número de estrofes, mas como todos os ideais, a solução é inalcançável. Dessa forma, nunca poderia surgir um texto legível. Nesse contexto, podemos novamente fazer referência a A. W. Schlegel (item 1.6.), que criticava J. H. Voss por ter agraciado o povo alemão com um Homero de pedra, um Aristófanes de couro e um Shakespeare de madeira. 


\subsubsection{Ponderações de cunho moral}

Aspectos morais pesam bastante. Em uma citação (vide item 2.1.2.) foi mencionado o que G. J. Göschen escreve como introdução à tradução de Tom J ones, por J. J. Chr. Bode: “[...] trechos que ofendem o gosto refinado foram sutilmente esmaecidos [...]"

Acerca de sua tradução de Aristófanes, Chr. M. Wieland escreve numa carta “Ao senhor H. V**” (J. H. Voss, RR) sobre duas dificuldades muito significativas do tradutor. A primeira delas são os enunciados imorais no original que "são contrários ao nosso sentimento de moralidade e a nossos conceitos de decência"; e a segunda delas são as alusões a circunstâncias temporais.

De acordo com A. W. Schlegel, muita coisa havia mudado desde os tempos de Shakespeare, especialmente em termos de usos e costumes: "Outro ponto é a decência de certas falas e expressões. Visto que a forma de pensar sobre o assunto baseia-se, em parte, nas convenções e, por isso, muda com as épocas, é apropriado e justo que se observe a sua própria época e evite choques desnecessários." (Prefácio a sua tradução de Hamlet, 1800).

No prefácio às Molieres Lustspiele und Possen [Comédias e farsas de Molière] (1805), Heinrich Zschokke escreve: "Se é para Molière ser bem recebido nos palcos alemães, não basta ele falar em língua alemã, mas também pensar e agir com espírito alemão. Nossa sensibilidade reluta em ver no palco ambiguidades nas palavras e nos atos, por mais que sejam aplaudidas pelos franceses; reluta em ver o respeito das crianças pelos pais e a fidelidade dos esposos sendo ridicularizados [...]. Sempre tendo em vista o palco alemão e a nossa época, nunca se deve esquecer que na tradução Molière deve falar como se tivesse vivido entre nós na Alemanha."

\subsection{Fidelidade}

Não é verdade que todas as concepções acerca da tradução à época de Goethe aprovassem o que foi dito sobre o tema adaptação e adequação. Uma dificuldade frequente é aceitar que o estilo do original não seja preservado. 
ROOTHAER, R. - Literatura universal: a tradução na época de Goethe

Alguns exemplos já foram citados. Alguns também expressam dúvidas sobre a tradução do verso em prosa e sobre o uso de determinadas formas de versificação.

\subsubsection{A moral não é motivo para alterações}

A inclinação de alguns tradutores por alterar ou excluir coisas que considerem imorais é bastante controversa.

No prefácio à sua tradução de Begebenheiten des Enkolp aus dem Satyricon von Petronius [Acontecimentos de Encólpio, do Satíricon de Petrônio], J. J. W. Heinse não deixa dúvidas sobre sua opinião: "Os poetas, os pintores e os romancistas têm sua própria moral. Seria uma exigência inapropriada esperar deles que trouxessem ao mundo nada além de Grandisons, ${ }^{12}$ madonas, crucifixos e messias. A moral das belas artes e das ciências mostra os seres humanos como eles são e como eles foram em todas as épocas, em enredos impressionantes, para seu deleite e como ensinamento e advertência geral. Concedemos ao gênio a liberdade de descrever e pintar tudo o que tenha acontecido e que possa ter acontecido [...].

Os gregos e todas as nações alegres [...] não tomavam as partes do corpo, das quais nós, pobres filhos e filhas da terra, - e nós nem mesmo sabemos por quê - costumamos envergonhar-nos tanto, como a coisa mais sagrada nos Céus e na Terra $[\ldots]$.

Não vos enraiveçais a meu respeito, que sou um pobre tradutor! Pois não pude fazer este Satyricon melhor do que já é [...]."

E aos 20 de maio de 1814, por ocasião da tradução de Die Wolken [As Nuvens], de Aristófanes, por Friedrich August Wolf, L. Tieck escreveu: “Acabo de ler as traduções de Aristófanes feitas por Wolf. Parece que seria necessário ter mais audácia para realmente se envolver com o velho brincalhão; só espero que ele não seja traduzido para moças ou lido para elas numa pensão."

\footnotetext{
12 Personagem principal do romance epistolar The History of Sir Charles Grandison, de Samuel Richardson, publicado em 1753, como resposta ao romance de The History of Tom J ones, a Foundling, que por sua vez parodia a moral de romances anteriores de Richardson. (N. d. T.)
} 


\subsubsection{Não existem motivos válidos para modificações}

Há tradutores que são da opinião de que não existem motivos válidos para desvios intencionais do original. Por ocasião da tradução de Shakespeare, em 1766, Chr. M. Wieland explica: "Pode haver uma razão muito boa para que o tradutor de um original que tem tantos grandes defeitos quanto grandes belezas e que, acima de tudo, seja incorreto e bruto no intuito da expressão, ache por bem traduzi-lo como está. Em milhares de trechos, a própria linguagem de Shakespeare é dura, rígida, túrgida e torta; e assim ele também é na tradução, pois se desejou apresentá-lo aos alemães tal como ele é [...]. Deixaria de ser Shakespeare tão logo quisessem embelezá-lo. Realmente, muito se fez quando o traduzimos de forma bastante fiel, como admite o nosso crítico [...]." (Trata-se de uma tradução em prosa (!). Ao que tudo indica, Wieland estava pensando apenas no conteúdo).

No prefácio à sua tradução de Hamlet (1800), A. W. Schlegel afirma que adaptações não devem ser feitas: "O preconceito sobre a corrigibilidade da obra de Shakespeare não deve ser creditada somente aos alemães, visto que ele foi trazido, em parte, da Inglaterra até nós [...]. Via-se a poesia à maneira da nobre arte da alfaiataria em que aquilo que saiu errado no primeiro talhe pode ser corrigido - mesmo que só em certa medida - por meio de remendos e recortes [...]. É natural que por esse caminho bem se possa destruir uma obra de arte, mas dificilmente criar uma, pois uma obra de arte verdadeira é um todo único e indivisível, e surge como tal."

Significado e forma devem ser preservados, também de acordo com Johann Jacob Breitinger, em Critische Dichtkunst [Arte poética crítica] (1740): "A tradução é um retrato que merece tanto mais louvor quanto mais semelhante for [ao original]. Por isso, um tradutor deve impor-se a dura lei de que jamais tomará a liberdade de desviar-se do escrito original, nem naquilo que concerne aos pensamentos, nem na forma e estilo dos mesmos. Estes devem permanecer inalterados numa mesma intensidade de luz e força, e apenas seus signos devem ser trocados por outros de igual valor. Milton devenos apresentar na tradução precisamente as mesmas imagens e descrições 
ROOTHAER, R. - Literatura universal: a tradução na época de Goethe

sublimes e maravilhosas, na exata ordem do original, e provocar na mente do leitor alemão exatamente os conceitos elevados e movimentos alternados que ele perceberia e sentiria se the fossem conhecidos os signos nos quais está investida a expressão em inglês." Infelizmente, ele não nos oferece nenhuma indicação sobre como alcançar este objetivo.

Chr. M. Wieland (revista Der Teutsche Merkur, 1782) escreve sobre a tradução da Odisseia, de Homero, por J. H. Voss: "A tradução é tão fiel que é quase possível chamá-la de literal; uma vantagem essencial que ela tem sobre todas as demais traduções métricas de Homero [...]". Além disso, ela é "genuína e pura em sua linguagem, livre de helenismos afetados, formulações estranhas, alterações severas, e afins; é, sobretudo, belamente versificada e tão fluente [...]. O fato de o senhor V. ter traduzido linha por linha é muito vantajoso, uma vez que ele não sacrificou em nome dessa precisão nem mesmo a menor das belezas do original."

Johann Jacob Bodmer diz em Von der erforderten Genauigkeit beym Übersetzen [Sobre a exatidão exigida na tradução] (1746): “Desejando-se, porém, ter uma tradução exata que não somente apresente os pensamentos do original, mas também preserve todas as maneiras que o autor utilizou para trazê-los à luz, é preciso, então, que isso também seja realizado de maneira exata, e não se pode temer ser responsabilizado por estranhezas inauditas ou, talvez, até por erros do original."

A. W. Schlegel alinha-se a essa posição (Die Horen [As Horas], v. 6, (1796), peça 4, pp. 109) e acredita ser a língua alemã muito apropriada: “Uma tradução poética que não apagou nenhuma das diferenças características da forma e preservou tanto quanto possível suas belezas, sem a pretensão de the emprestar outras; seria certamente uma empresa de dificuldades grandes, mas não insuperáveis em nossa língua."

\subsubsection{Modificações podem ser inevitáveis}

É completamente impossível traduzir tudo fielmente, diz Johann Nicolaus Götz sobre sua tradução conjunta com Johann Peter Uz, de Die 
Gedichte Anakreons und der Sappho Oden [As poesias de Anacreonte e as Odes de Safo], em uma carta a J. W. L. Gleim: “[...] não alteramos deliberadamente nenhuma expressão que continha alusões a hábitos e histórias de seu tempo; evitamos quaisquer mudanças no pensamento, quaisquer reformulações do texto grego, quaisquer acréscimos, quaisquer expansões das imagens, desde que fosse possível qualquer aumento do número de linhas, mas sem fazer disso uma lei inviolável."

Moses Mendelsohn faz de sua tradução de Die Psalmen [Os Salmos] um elogio a Lutero: "Estava tão pouco apaixonado pela inovação que, no que se refere à linguagem, mantive-me mais próximo do Dr. Lutero que de tradutores posteriores. Onde este traduziu corretamente, pareceu-me também ter germanizado de maneira apropriada: e sequer evitei as locuções hebraicas que ele incorporara à língua, por mais que elas não sejam genuinamente alemãs."

Christlob Mylius escreve em Cândido (1782) uma Profissão de Fé do Tradutor [Glaubensbekenntnis als Uebersetzer]: “Creio firmemente que um tradutor deva ater-se com máxima exatidão ao original e deva traduzir-lhe fielmente cada expressão, cada uso figurado, desde que estes em nada querelem contra o gênio da língua nem tenham algo que escandalize o gosto de seu povo. Creio que ele não deve ousar nem esclarecer o que o autor ocultou numa penumbra misteriosa, nem atenuar o ponto onde este se mostra nervoso, nem tampouco robustecê-lo onde se apresenta débil, a não ser que a língua coloque barreiras absolutamente intransponíveis em seu caminho, de modo que ele tenha de restituir de outras maneiras o que não esteve em condições de oferecer em outras passagens como, por exemplo, nos jogos de palavras e afins; e, finalmente, que sempre deixe transparecer o autor inglês, o francês, o italiano ou o espanhol [...]. Jamais me parece haver um elogio a uma tradução quando dizem que ela é lida plenamente como no original; isso é um indício certo de que todas as características nacionais do autor foram apagadas."

Por fim, citemos ainda W. von Humboldt, com sua introdução à tradução de Agamêmnon, de Ésquilo, como exemplo para aqueles que consideram que uma tradução deva ser fiel, que deva fazer sentir o sabor do elemento 
ROOTHAER, R. - Literatura universal: a tradução na época de Goethe

estrangeiro, sem que a língua de chegada cause estranhamento. Deve-se chegar a uma espécie de meio-termo entre as exigências do original e da língua de chegada: "Havendo, entretanto, o caso de a tradução apropriar à língua e ao espírito da nação aquilo que ela não possui, ou possui de outra maneira, a primeira exigência será, então, a simples fidelidade. Essa fidelidade deve ser direcionada ao verdadeiro caráter do original e não [...] a suas contingências, assim como toda boa tradução, geralmente, deve partir do amor simples e despretensioso pelo original e do estudo que deste surge, e a ele deve retornar. Porém, necessariamente associado a essa perspectiva, está o fato de que a tradução carrega consigo certa cor da alteridade. Contudo, são facilmente traçáveis os limites em que isso se torna um erro inegável. Tão logo se fizer sentir não a alteridade, mas o elemento estrangeiro, a tradução terá atingido seu ponto alto; por outro lado, onde surgir a alteridade per se, e talvez até fizer obscurecer o elemento estrangeiro, revela-se que o tradutor não está à altura de seu original [...]. Se prosseguirmos com temor repulsivo diante do incomum e desejarmos evitar mesmo o elemento estrangeiro, assim como geralmente se ouve dizer que o tradutor deveria escrever como o autor do original escreveria na língua do original, [...] destrói-se, então, toda a tradução e todos os seus benefícios para a língua e a nação.”

\subsubsection{Compensações}

A meu ver, as considerações acima ainda exigem uma complementação, como diz Friedrich Schiller em seu prefácio a Die Zerstörung von Troja. Zweites Buch der Aeneide, übersetzt vom Herausgeber [A destruição de Troia. Segundo livro da Eneida, traduzido pelo editor]: "A principal dificuldade [...] foi a escolha de um estilo de verso com o qual as virtudes do original sofressem menos perdas, e que, em certa medida, pudesse substituir aquilo que já deve se perder inevitavelmente, só por conta da diferença linguística." 0 fato de que uma tradução não pode ser fiel até o menor detalhe, mas que o tradutor ocasionalmente pode compensar uma perda por um ganho, é mencionado por ele também em uma carta já citada, de 10 de abril de 1791, endereçada a Chr. 
G. Körner. Pode-se, portanto, traduzir fielmente quando se segue a regra de W. von Humboldt: "Essa fidelidade deve ser direcionada ao verdadeiro caráter do original e não [...] às suas contingências".

\subsubsection{O leitor deve fazer sua parte}

Na direção contrária ao conceito de "germanização", de acordo com a qual o tradutor dever ir em direção ao leitor com sua tradução, ou seja, adaptando ou recriando, como louva, por exemplo, W. Chr. S. Mylius em seu já citado prefácio ao Cândido, de Voltaire (item 2.1), consta uma ideia raramente mencionada à época de Goethe: a de que traduções existem para aqueles que não são versados numa língua estrangeira, mas querem ler a obra por interesse pela narrativa e por curiosidade acerca da produção cultural estrangeira. Por isso, é compreensível que, caso se queira atender à exigência de Wilhelm von Humboldt, deve-se preservar o elemento estrangeiro numa tradução e forçar o leitor, por sua vez, a fazer os esforços necessários para penetrar no universo estrangeiro. Nesse caso, as notas podem prestar um bom auxílio. À época de Goethe, tal como hoje, havia muitas delas como complemento. Ademais, o leitor pode também consultar outras obras.

Segundo J. W. von Goethe (em seu Logenrede [Discurso de Ioja maçônica]), Chr. M. Wieland tomou uma posição intermediária entre as duas concepções sobre a tradução: "Há duas máximas da tradução: uma demanda que o autor de uma nação estrangeira seja trazido até nós de tal forma que possamos vê-lo como um dos nossos, a segunda faz-nos a exigência de que nós nos dirijamos ao estrangeiro e encontremo-nos em suas situações, em seu modo de falar e suas peculiaridades [...]."

A segunda "máxima" é defendida no prefácio a Minnelieder aus dem Schwäbischen Zeitalter, neu bearbeitet und herausgegeben von L. Tieck [Canções dos trovadores da era suábia, reeditadas e publicadas por L. Tieck] (1803): "Pareceu-me mais importante não mudar em nada a natureza do caráter do poema e de sua língua; por isso a forma do verso não podia ser ferida. Entretanto, não foi possível evitar isso quando eu não deixava algumas palavras 
ROOTHAER, R. - Literatura universal: a tradução na época de Goethe

antigas tais como eram empregadas originalmente. $\mathrm{Na}$ linguagem mais moderna, todos esses poemas perdem muito. Por isso, o editor não faz uma exigência insensata quando solicita que os leitores devam encontrá-lo no meio do caminho até ele, da mesma forma que ele percorre metade do caminho até encontrá-los."

J. H. Voss foi o tradutor que aplicou essa concepção até as últimas consequências, de tal maneira que ele, por exemplo, seguia a forma do verso original até o mínimo detalhe. O leitor tinha de se preocupar em assimilar o elemento estrangeiro da língua e do verso e compreender o significado numa forma de expressão que muitas vezes aparentava ser forçada.

\section{Semelhanças e diferenças}

Uma importante diferença em relação ao método de como os problemas tradutórios são tratados hoje em dia pode ser formulada da seguinte maneira: à época de Goethe - e, na verdade, até pouco tempo atrás - os tradutores não procuravam investigar objetivamente como se faz a melhor tradução, mas eles mostravam em suas reflexões teóricas a preferência que davam a um método de tradução. Hoje também se traduz tendo-se por base as próprias concepções subjetivas acerca de uma boa tradução, mas quando alguém se aventura em considerações de cunho teórico, será necessário recorrer a uma teoria de tradução - certamente ainda não plenamente harmonizada.

$\mathrm{Na}$ discussão de alguns aspectos da tradução relacionados aos autores e tradutores citados, já ressaltei uma quantidade de pontos de consenso e, em menor quantidade, de diferenças com as concepções contemporâneas. Talvez seja possível afirmar, sem gerar muita controvérsia, que os problemas da tradução literária (expressiva) permanecem inalterados, pois a teoria da tradução ainda não pôde expressar-se definitivamente sobre o tema. 
O tradutor se compromete, de acordo com suas convicções, com a absoluta fidelidade para então exigir novamente a liberdade de interpretação, como o fizeram, por exemplo, Wieland e Schiller.

Visto que de qualquer maneira ainda não existe uma convicção geral sobre a melhor forma de traduzir, muitas vezes classificam-se também adequações e adaptações sob o rótulo de tradução, e ainda existem exemplos de traduções que defendem a opinião de que nem o conteúdo nem a forma devem ser preservados em todos os detalhes. Talvez, igualmente como antes, prevaleça o consenso somente na convicção de que nenhuma tradução - por mais fiel que seja em relação ao conteúdo e à forma - pode alcançar a absoluta fidelidade, de que, por natureza, em toda tradução existem desvios e muitas vezes até mesmo perdas hão de ser contabilizadas. Absolutamente essencial permanece em cada tradução a reprodução fiel de uma cultura estrangeira em todos os seus aspectos. Esses problemas surgem principalmente quando são traduzidas obras africanas, japonesas ou chinesas, isto é, de culturas estrangeiras mais distantes. Todavia, há o fato de que a maior parte das traduções literárias é feita dentro de um círculo cultural europeu - ocidental, poderíamos ainda dizer - "uno" que hoje se expande muito mais do que anteriormente.

Quando se assume uma perspectiva quantitativa, pode-se defender a posição de que, muito diferentemente da época de Goethe, os problemas da tradução literária tornaram-se proporcionalmente menos graves.

Traduzem hoje principalmente pessoas sem aspirações literárias. A tradução é praticada por razões pragmáticas, ou seja, os textos a serem traduzidos pertencem à categoria dos textos informativos. 0 objetivo da maior parte das traduções é completamente diferente do que era antigamente. Visto que se trata de textos científicos, tecnológicos e afins, mudanças no conteúdo não passam pela cabeça do tradutor. E ele não deve fazê-lo, pois a informação deve ser transposta corretamente. Além disso não há pressão para tanto, pois os textos - seja na Europa, seja em outros lugares - não pertencem a círculos culturais diferentes. Os problemas que surgem devido ao tempo e espaço são 
ROOTHAER, R. - Literatura universal: a tradução na época de Goethe

quase irrelevantes. Naturalmente isso se aplica também a todos os textos jurídicos e administrativos, que, entre outras, são produzidos em profusão pelas instâncias europeias.

Quando for necessário escolher entre preservar a forma ou o conteúdo nesses textos, a escolha sempre recairá sobre o conteúdo e a terminologia exata. A organização dos pensamentos deve ser transposta corretamente. Assim, uma tradução do ramo jurídico exige um conhecimento exato da terminologia em questão, tanto na língua de partida quando na de chegada. 0 mesmo se aplica, naturalmente, para todas as outras áreas que oferecem a tradução de textos informativos.

Que seja dito enfaticamente: o tradutor deve, em último caso, sacrificar a forma em prol do conteúdo. Somente quando a forma também estiver bem acomodada é que a tradução de um texto informativo poderá ser chamada de tradução. Mas, seja como for, as demandas formais são menos severas. A ordenação do texto, por exemplo, deve ser preservada: um texto jurídico deve manter seu estilo jurídico. Isto também vale para a forma na língua de chegada: ser tão fiel quanto possível.

A esta altura não é possível produzir uma análise de textos informativos ou de outros gêneros textuais apelativos que não foram discutidos aqui. Tal análise também não precisa ocorrer primariamente na tradutologia. No entanto, é evidente que os problemas permanecem inalterados e sem solução. Mas é igualmente claro que, em função das diferentes épocas, a importância dos diferentes aspectos é deslocada ora para o primeiro, ora para segundo plano.

A tradução é tão vinculada ao tempo quanto a língua e a cultura: o essencial permanece, o secundário modifica-se. Mais ainda: a questão em torno daquilo que é essencial e daquilo que é secundário pode ser respondida de forma diferente no tempo e no espaço. No entanto, um aspecto parece ser irrefutável: a tradução não pode ser fiel e, portanto, também não pode ser boa se o conteúdo não for reproduzido corretamente. Mesmo a época de Goethe, intensamente voltada à literatura, não questiona esse fato. 
A forma, no entanto, continua a ser um eterno ponto de discórdia, especialmente quando se trata de textos expressivos (ou de elementos expressivos nos textos).

Há (ou haveria) de mudar a situação uma teoria científica da tradução assentada em fundamentos objetivos? Afinal, toda tradução está baseada numa liberdade condicionada, em decisões tomadas pelo tradutor dentro dos limites da língua de partida, sendo que a língua de chegada e o pano de fundo cultural de ambas as línguas estão envolvidos nessas decisões.

Será que reside aí a explicação de não existir a tradução ideal? 